\title{
Poszukiwanie sensu wobec postmodernizmu, relatywizmu i ironii
}

KS. DR hAB. Michaє DrożDż, PROF. UPJPII

Uniwersytet Papieski Jana Pawła II w Krakowie

\section{Wstęp}

Na początek garść osobistych wspomnien. Arcybiskup Józef Życiński pozostaje w mojej pamięci jako człowiek, który się spalał. Jak sam mówił, szkoda czasu, aby się w życiu tylko tlić, dając przy tym dużo dymu wokół siebie, trzeba się spalać, trzeba płonąć, i sam tak żył... Spalał się w szerokim spektrum swoich prac - naukowych, pasterskich, ludzkich...

Kiedyś, jako mój Biskup, podarował mi książkę o czasie, mówiąc przy okazji: czas jest nieodwracalny, czas nie wraca, trzeba go dobrze wykorzystać, tylko wieczność jest aczasowa... To mnie zainspirowało do tematu pracy na temat nieodwracalności struktury czasu: przeszłość, teraźniejszość, przyszłość. Nieodwracalności czasu, bo mówimy o nim w naszej teraźniejszości w czasie przeszłym, ale czerpiemy z jego życia wiele pięknych momentów do naszej przyszłości. 
Był człowiekiem wielkiego umysłu i wielkiego serca, wrażliwym na ludzką biedę, na potrzeby ludzi, na różne ludzkie duchowe i materialne biedy, wrażliwym na drugiego człowieka. Miał tę umiejętność przechodzenia ze świata akademickiej dyskusji do rozmowy z dziećmi, z chorymi i potrzebującymi. Jego troską było wychowanie młodego pokolenia wobec wyzwań cywilizacji medialnej: dzień przed śmiercią referował w Kongregacji Wychowania Katolickiego projekt dokumentu o roli Internetu w formacji kleryckiej i kapłańskiej. Jego troską była ewangelizacja współczesnej kultury, przenikanie jej duchem Ewangelii, nie tylko chodziło mu o obecność wartości chrześcijańskich w kulturze, ale o ewangelizację kultury, jako członek Papieskiej Rady Kultury tak widział nową ewangelizację.

Arcybiskup Józef Życiński podejmował odważny dialog ze współczesnymi tendencjami kulturowo-cywilizacyjnymi, obecnymi przede wszystkim w dyskursie filozoficznym, ale również w przestrzeni współczesnej kultury medialnej.

Potrafił on wykorzystać potencjał mediów w dziele ewangelizacji, ale potrafił także demaskować fałszywe stereotypy, odkrywać błędne ścieżki destrukcyjnych poglądów, odważnie występując w mediach z przesłaniem wartości w kontekście różnych spraw społecznie, kulturowo i ewangelizacyjnie ważnych.

Był rzeczywiście człowiekiem obecnym w przestrzeni medialnej, co narażało go na różność ocen, może czasem bardzo krytycznych. Niezależnie jednak od tej różności 
potocznego wartościowania jego medialnej obecności warto i należy docenić trafność jego analiz i diagnoz współczesnych tendencji obecnych i promowanych w kulturze medialnej.

Moje analizy, opierając się na tekstach abp. Józefa Życińskiego, są próbą poszukiwania odpowiedzi na pytanie: w jakim stopniu współczesna kultura medialna odzwierciedla i promuje postmodernistyczne tendencje kulturowe prowadzące z jednej strony do destrukcji personalistycznej filozofii sensu, a z drugiej strony „produkuje nowy sens” oparty na etyce sytuacyjnej i utylitarystycznej. W tym kontekście staram się z perspektywy myśli abp. Józefa Życińskiego odpowiedzieć na pytanie, jaki świat wartości i sensu odsłania się w przekazach mediów, i odwrotnie, w jaki sposób współczesne tendencje filozoficzno-kulturowe, mentalność postmodernistyczna, która jest zdemaskowana na płaszczyźnie dyskursu filozoficznego, wpływa na rozlewającą się w przekazach medialnych wizję świata.

\section{Sprzeciw wobec cyrku cywilizacji, która sprzedaje się za małość}

W Elementarzu księdza Życińskiego dla biskupa i świeckiego możemy przeczytać jego słowa: „[...] następstwem programowego odrzucenia wielkiej tradycji intelektualnej bywa zjawisko nazywane przez Herlinga-Grudzińskiego «cyrkiem cywilizacji, która utraciła wiarę w siebie i sprzedała się za małość», przyjęte entuzjastycznie przez zastępy 
niewolników ideologii wyzwolenia”. „Znamienne cechy tzw. mentalności postmodernistycznej stanowią: brak zaangażowania intelektualnego i niewrażliwość na ideały moralne, podważanie możliwości osiągnięcia obiektywnej prawdy, negowanie istnienia obiektywnych wartości, pesymizm towarzyszący utracie wiary. Wszystko to prowadzi do tworzenia ulotnego sensu, do propozycji życia traktowanego jako happening, w którym łatwo jest wynieść na piedestał prymitywizm, miernotę czy gładkie slogany pozbawione merytorycznego uzasadnienia" ${ }^{2}$.

„Produkcja sensu” w dzisiejszym świecie medialnym odpowiada tej diagnozie. Myślę o medialnym tworzeniu takich idei i takiego klimatu konsumpcji, że tylko w niewielkim zakresie uzasadniają one racje twórczych wysiłków ludzi i nie służą pełnemu rozwojowi duchowemu człowieka. Media dostarczają ludziom uniwersalnych schematów, standardowych wzorców, sytuacyjnych kryteriów ocen, gotowych $i$ łatwych recept na sukces i szczęście. Ta produkcja przyczynia się do umacniania czy - mówiąc językiem Gerbnera - kultywowania postaw konsumistycznych poprzez procesy uśredniania. Pierwszy sposób działania mediów jest to „uśrednianie” opinii, zachowań, postaw odbiorców poprzez permanentne oddziaływanie na nich tymi samymi obrazami, hasłami, ideami. Konsekwencją uśredniania

1 J. Życiński, Elementarzu księdza Życińskiego dla biskupa i świeckiego, teksty wybrał i ułożył T. Kunz, Kraków 2002, s. 107 (dalej jako EŻ).

2 Tamże, s. 105. 
przekazów jest również „uśrednianie” odbiorców oraz promowanie fałszywie pojętej tolerancji, usprawiedliwiającej wszelkie dewiacje, anormalności i mniejszościowe opinie. Ludzie są niejako wessani przez medialnie lansowany nurt kultury w sferę medialnych wzorców, poglądów, opinii, mody itp. Tę sferę określa Gerbner mianem „nowego populizmu", wciągającego coraz szerszą rzeszę odbiorców poprzez mechanizmy uśredniania, ujednolicania czy spłycania do poziomu taniej przeciętności oraz medialnie lansowanej poprawności kulturowej, utrwalającej konformizm ocen i działań.

„W tej perspektywie całe życie można traktować jako swoisty happening. Ironizujący błazen pełni wtedy funkcję nauczyciela i kapłana zarazem. Błyskotliwy styl programowych ironistów oraz poczucie humoru nie przemęczające szarych komórek są łatwe w recepcji i nie nakładają żadnych zobowiązań moralnych. Ich kulturowym następstwem pozostaje aksjologiczna i intelektualna pustka cywilizacji, z której usunięto ideały kształtujące wzorce myślenia oraz wartościowań etycznych od czasów presokratyków"3.

Życie przedstawiane w takiej konwencji jest nieustannym pasmem gry i zabawy, przypadkowych interakcji i indywidualnych doznań. Tę medialną „zabawę na śmierć” którą diagnozuje arcybiskup Życiński, sugestywnie prezentuje w swoich publikacjach Neil Postman. „Problem

3 Tamże, s. 107. 
polega nie na tym - pisze Postman - że telewizja przedstawia nam rozrywkową tematykę, ale na tym, że wszelka tematyka przedstawiana jest jako rozrywka [...] że telewizja uczyniła z rozrywki naturalny format, w którym przedstawia wszelkie doznania" ${ }^{4}$. Trzeba zauważyć, że opisane przez Postmana procesy degradacji i eliminacji racjonalnego dyskursu z mediów nie są zdeterminowane przez samą „naturę” przekazów medialnych, a więc nie przez formy językowe, lecz raczej przez treść przekazu i procesy komercjalizacji mediów. Postman pokazuje, że we wszechwładnej epoce mediów i „show-biznesu”' życie prezentowane czy odgrywane na ekranie okazuje się ważniejsze od rzeczywistości, a medialne emocje skutecznie redukują świat ludzkich przeżyć.

\section{Człowiekowi nie wystarczy żyć w „sztucznych światach" medialnych}

Istnieje w mediach silny kulturowy wpływ myśli postmodernistycznej, negującej obiektywny związek między znakiem a jego znaczeniem. Derrida i Baudrillard negują istnienie znaczenia samego w sobie. Dla nich - jak pisze

4 N. Postman, Zabawić się na śmierć. Dyskurs publiczny w epoce show-businessu, tłum. L. Niedzielski, Warszawa 2002, s. 130.

5 Por. N. Postman, Das Zeitalter des Showbusiness, w: Kursbuch Medienkultur. Die maßgeblichen Theorien von Brecht bis Baudrillard, red. C. Pias $\mathrm{i}$ in., Stuttgart 2000, s. 223-233. 
Olson - „nic niczego nie oznacza”. Ta teza staje się dla nich podstawą reinterpretacji procesów komunikowania medialnego, które operuje przecież systemem znaków i symboli. Zgodnie $z$ ich koncepcją znak i symbol nie odnoszą się do żadnej rzeczywistości oznaczanej, a ,jedynie do innych znaczących w nieprzerwanym samoreferencjalnym łańcuchu znaczeń, który nie odsyła do żadnego zjawiska zewnętrznego"7. Zgodnie z taką koncepcją nie istnieje zatem żadna rzeczywistość obiektywna, doświadczenie zewnętrzne, poza samym procesem oznaczania, ponieważ każde doświadczenie czy każda rzeczywistość jest tylko efektem dyskursu semantycznego, prowadzonego w całym procesie oznaczania. Język nie jest zatem nośnikiem obiektywnych znaczeń, ale staje się narzędziem dyskursu komunikacyjnego, w którym pojawia się cały szereg dowolnych konstruowanych przez podmioty komunikacji. Tak język medialny staje się w konsekwencji narzędziem gry, dyskursu, dowolności i subiektywności ludzkich konstrukcji myślowych oraz autonomiczności w ich konstruowaniu, poznawaniu i praktycznym stosowaniu. Ta tendencja sprawia, że gubi się obiektywny sens słowa.

6 S.R. Olson, Teoria komunikowania: ponowne rozpatrzenie kwestii, w: Współczesne systemy komunikowania, red. B. Dobek-Ostrowska, Wrocław 1998, s. 51.

7 Por. K. Stasiuk, Krytyka kultury jako krytyka komunikacji. Pomiędzy działaniem komunikacyjnym, dyskursem a kultura masowa, Wrocław 2003, s. 36 . 
„W perspektywie postmodernistycznej nie ma miejsca na pojęcie prawdy. Postmodernistyczny Piłat nie musi dręczyć się pytaniem «co to jest prawda?» Wystarczy, że umyje ręce, zasypując słuchaczy porcją nowych dowcipów. [...] Postmodernizm stwarza wyjątkowo rozległe pole do działania dla tych, którzy rozgłos cenią znacznie wyżej niż odpowiedzialność. Można w nim na racjonalne, głębokie pytania odpowiadać kpiną. Można dowolny problem sprowadzić do poziomu błyskotliwej gry słów, można tworzyć sztuczne światy pustej nowomowy. Jest to znakomita propozycja dla tych, którzy w filozofii mają bardzo niewiele do powiedzenia, ale chcieliby to powiedzieć stylowo i z wdziękiem".

Konsekwencją epistemologiczną postmodernistycznego negowania prawdy jest zmiana perspektywy postrzegania rzeczywistości. Media nie tyle odzwierciedlają rzeczywistość, ale ją kreują, prawdy się nie odkrywa, bo jej nie ma w tej perspektywie myślenia, tylko się ją kreuje, tworzy. Świat kreowany przez media jest sztuczną konstrukcją, zależną od naszego poznania. Chodzi tu o kreatywną rolę mediów w tworzeniu i „produkowaniu” sensu, nie tylko w aspekcie strukturalno-semiologicznym subiektywnych procesów dekodowania treści medialnych przez odbiorcę, ale przede wszystkim $\mathrm{w}$ aspekcie nowej ontologii medialnej, zgodnie z którą media kreują sztuczny świat, nową rzeczywistość wraz z zawartym w niej sensem.

8 EŻ, s. 106. 


\section{Zatrzymać banalizację zła w przekazach medialnych}

„W retoryce współczesnego relatywizmu zło zostaje zbanalizowane i okryte głęboką warstwą zdroworozsądkowych sloganów wyciszających wewnętrznie" ${ }^{9}$. Te procesy widoczne są szczególnie w mediach tabloidowych. Życiński uważa, że ta praktyka kodów tabloidowych nie świadczy o tym, iż zanika świadomość zła, ale raczej o tym, iż zło jest banalizowane oraz że zanika zdolność prawidłowego wartościowania etycznego, w którym „rozróżnienie danego czynu bądź zachowania i jego utożsamienie ze złem staje się problematyczne"10. We współczesnej masowej kulturze medialnej odzwierciedlają się pewne negatywne tendencje mentalności kulturowej, promujące banalność, wulgarność, prymitywność, absolutną swobodę itp. Tendencje te przyczyniają się niewątpliwie do zacierania granic między dobrem a złem, pogłębiając stan zamieszania etycznego. Ta tendencja ma negatywny wpływ na wrażliwość moralną człowieka, tak iż wielu ludzi nie operuje już w języku codziennym pojęciem zła, ale nazywa je pojęciami zastępczymi: niestosownością, brakiem kultury, nielojalnością, niesubordynacją, naruszaniem porządku itp., które częściowo usprawiedliwiają zło lub je banalizują. W wielu współczesnych opracowaniach etycznych dotyczących

\footnotetext{
9 Tamże, s. 103.

10 Tamże.
} 
funkcjonowania telewizji i Internetu wyraźnie mówi się o coraz powszechniejszym zjawisku banalizacji zła. Media posługują się tak zwanym efektem widoczności, eksponując czasem w nadmiarze zjawiska negatywne, czyniąc z nich główną siłę własnej atrakcyjności. Ten negatywny moralnie obraz świata może podważać lub deprecjonować akceptowany przez odbiorców prawdziwy świat wartości, zwłaszcza gdy negatywne wartości ukazywane są w oprawie normalności i atrakcyjności. Konsekwencją takiego działania może być postępujące lekceważenie i banalizacja zła. Proces ten może prowadzić do hipertrofii niewrażliwości na zło, to znaczy, że następuje systematyczna substytucja tego, co dobre, na gorsze, gorszego na złe, nadmiaru na zwyczajność, zwyczajności na nienormalność itd., substytucja, która w końcu zaciera granice pomiędzy dobrem a złem. Substytucja tego typu jest tym łatwiejsza, że służy jej język banalizujący zło, np. słowo „zabić” zastępowane jest wyrażeniem „zadawanie śmierci z litości”, „kradzież” jest określana jako „zabranie rzeczy”, „kłamstwo” jako „niewyjaśnialna sprawa”, „zniewolenie” jako „kształtowanie nowej wyobraźni”, „pornografia” jako „język ciała” itp. „W naszych czasach - pisze Paul Valadier - trzeba skupić uwagę na psuciu języka, który przez kolejne ześlizgnięcia czyni ze zła dobro" ${ }^{11}$. Widzimy czasem, jak dopiero tragedie i afery budzą sumienia $\mathrm{z}$ tego medialnego zamętu

${ }_{11}$ P. Valadier, Pochwała sumienia, tłum. M. Żerańska, Warszawa 1994, S. 131. 
wartościowania etycznego. Media masowe, ze względu na swoją siłę i zakres, stanowią najbardziej skuteczny faktor warunkujący stan ludzkich sumień, oddziałując albo pozytywnie, albo negatywnie na człowieka.

\section{Nie kupować sprzedawanych medialnie "gotowców" sukcesu i szczęścia}

„Puste miejsce po zdetronizowanych absolutach najłatwiej wypełniać, podnosząc do rangi absolutu wartości, które mają przygodny i ograniczony charakter" ${ }^{\prime 2}$.

Media mają coraz większą siłę oddziaływania, ponieważ prezentują ludziom gotowe schematy, opinie, wzorce wartościowania i recepty na sukces i szczęście. Zasadniczo nie pokazuje się wysiłku w dochodzeniu do zdobycia takiego czy innego dobrego efektu. Stąd też ludzie mogą $\mathrm{z}$ łatwością wpadać $\mathrm{w}$ iluzję możliwości łatwego zdobycia „życiowego sukcesu”. Większość przekazów medialnych prezentuje "gotowce" łatwego i szybkiego sukcesu oraz prostą, schematyczną drogę łatwego szczęścia. Tabloidy prezentują tylko „gotowe efekty”. Procesy te nie dają możliwości pełnego urzeczywistniania się wolności i godności ludzkiej, rozwoju różnych talentów każdego człowieka oraz nie pomagają w budowaniu prawdziwego ludzkiego szczęścia na fundamencie prawdziwego sensu życia. „Lekcja pustyni wyzwala nas z tęsknoty za doraźnymi łatwymi

${ }_{12}$ EŻ, s. 42.

Poszukiwanie sensu wobec postmodernizmu, relatywizmu i ironii · 191 
rozwiązaniami, które w każdym czasie serwować będą grający na upodobaniach tłumów kolejni odkrywcy «jedynie słusznych» zasad. Uczy ona rezerwy wobec chwytliwych półśrodków, które w intencjach twórców mają rodzić powszechny zachwyt i urzekać prostotą porywających haseł sukcesu i szczęścia”"13.

\section{Potrzeba mądrości wobec intelektualnej pychy i irracjonalności}

„Mądrości odkrywanej w filozoficznej refleksji nie można redukować do estetycznych doznań czy kolorowych przerywników na szarym horyzoncie codziennych ścieżek. Mądrość ta pozostanie jedynie karykaturą mądrości, jeśli nie będzie znaczyć praktyki naszego życia" ${ }^{14}$. Arcybiskup, wskazując na potrzebę mądrości wobec intelektualnej pychy i irracjonalności, przywołuje jeszcze jeden tekst, który pochodzi z encykliki Fides et ratio. Dotyczy on potrzeby intelektualnej pokory wobec Tajemnicy Mądrości, mysterium fascinosum. „Różne systemy filozoficzne wpoiły mu złudne przekonanie, że jest absolutnym panem samego siebie, że może samodzielnie decydować o swoim losie i przyszłości, polegając wyłącznie na sobie i na własnych siłach. Wielkość człowieka nigdy nie urzeczywistni się w ten sposób. Stanie się to możliwe tylko wówczas, gdy człowiek postanowi

\footnotetext{
13 Tamże, s. 51.

14 Tamże, s. 109-110.
} 
zakorzenić się w prawdzie, budując swój dom w cieniu Mądrości i w nim zamieszkując"15.

Arcybiskup Józef w swojej trosce o racjonalność myślenia sprzeciwiał się swoistemu kultowi ludzkiego rozumu, który absolutyzował drogę naukowego poznania, często ze szkodą dla samej nauki, czyniąc z niej „nową religię". W historii myśli ludzkiej, a zwłaszcza w tak zwanych koncepcjach „postępu”, w skrajnych nurtach racjonalizmu i empiryzmu, wielokrotnie odwoływano się do ogromnych możliwości poznawczych człowieka i do jego osiągnięć naukowo-technicznych, niejednokrotnie je fałszywie absolutyzując. W parze z nimi szła często negacja moralności, duchowości, Transcendencji, której skutkiem było wykorzystanie owoców ludzkiego poznania i działania, a więc również techniki, przeciwko samemu człowiekowi, do tego stopnia, że zamiast postępu ludzkości dokonywała się jej moralna degradacja. Tak o tym pisze Jan Paweł II w książce Przekroczyć próg nadziei: „Rewolucja Francuska podczas terroru zburzyła ołtarze poświęcone Chrystusowi, powaliła przydrożne krzyże, wprowadziła natomiast kult bogini rozumu. Na gruncie tego kultu deklarowała wolność, równość i braterstwo. W ten sposób duchowe, a w szczególności moralne dziedzictwo chrześcijaństwa zostało wyrwane ze swego podłoża ewangelicznego, do którego trzeba go znów doprowadzić, by odnalazło swą pełną żywotność. [...] Co to oznaczało?

15 Jan Paweł II, Encyklika Fides et ratio, Watykan 1998, nr 107. 
Oznaczało to, że człowiek powinien żyć, kierując się tylko własnym rozumem, tak jakby Bóg nie istniał. Nie tylko wypada poznawać świat obiektywnie, tak jakby Bóg nie istniał, gdyż założenie istnienia Stwórcy czy Opatrzności nie jest nauce na nic potrzebne, ale trzeba również postępować tak, jakby Bóg nie istniał"16. Ta analiza pokazuje jedno ze źródeł nowożytnego i współczesnego ateizmu, głoszonego czasem w majestacie nauki, co jest jednym $z$ podstawowych błędów metodologicznych, a który do dziś powiela wielu quasi-naukowców, którzy - jak pisze Alan Sokal, głoszą w swoich publikacjach i w mediach "modne bzdury" ${ }^{17}$.

Nauka powinna - w myśli Życińskiego - demaskować zaściankowość i postawy ekskluzywizmu oraz odkrywać i pokazywać bzdury i mity współczesnego myślenia lub jego całkowitego braku, powinna odsłaniać wartość i potrzebę racjonalności we wszystkich obszarach ludzkiego zaangażowania w odkrywanie sensu wartości i celu, także w kontekście współczesnego relatywizmu i ironii, obecnych w kulturze współczesnej. „Istnieje pewna sfera obiektywnych ludzkich wartości, których nie jest w stanie usunąć żaden przełom deklarowany czy to przez media, polityków, czy filozofów. Świat, w którym brakłoby pojęcia prawdy, wierności czy altruizmu, byłby światem nieludzkim, nawet

\footnotetext{
16 Jan Paweł II, Przekroczyć próg nadziei, Lublin 1994, s. 56-57.

17 Por. A. Sokal, J. Bricmont, Modne bzdury. O nadużywaniu pojęć z zakresu nauk ścisłych przez postmodernistycznych intelektualistów, tłum. P. Amsterdamski, Warszawa 1999, s. 59 i nast.
} 
gdyby entuzjaści nowego ładu upatrywali w nim zalążków nowej ludzkości"18 - pisał arcybiskup Józef Życiński.

Dążenie do prawdy, mimo różnych przeszkód, błędów i ograniczeń możliwości poznawczych człowieka, jest podstawową powinnością moralną osoby ludzkiej, która jest zdolna wartościować wszelkie swoje działania w oparciu o swoją podstawową zasadę etyczną poszanowania prawdy, zasadę prawdomówności. Tak więc możemy mówić o potrzebie moralności myślenia, jak pisze w swojej książce pod takim tytułem ks. prof. Michał Heller. Potrzeba moralności myślenia jawi się szczególnie konieczną wobec irracjonalności, która „sieje spustoszenie nie tylko na własnym podwórku [...] irracjonalność w skali społecznej to prawdziwy kataklizm. Niestety, historia ludzkości dostarcza silnego poparcia tezie głoszącej, że ludzkość musi się jeszcze sporo napracować, zanim osiągnie stan używania rozumu. Racjonalność jest moralnością myślenia, czyli po prostu częścią etyki. Niemoralność nie jest chorobą, lecz grzechem. Szaleństwo irracjonalności polega na tym, że grzech stawia się na miejscu Wartości"19. Szaleństwo irracjonalności może się także pojawić w nauce, i dlatego potrzebna jest etyka badań naukowych, która pozwoli dostrzec i nazwać zło stawiane na miejscu dobra jako konsekwencję braku elementarnej moralności myślenia.

\footnotetext{
18 Ėं, s. 41.

19 M. Heller, Moralność myślenia, Tarnów 1993, s. 25.
} 


\section{Być człowiekiem dialogu}

„Najlepszą formą ewangelizacji współczesnego świata jest dialog, najlepszą formą komunikacji ze współczesnym człowiekiem jest dialog"20. Arcybiskup był człowiekiem wielorakiego dialogu. Starał się pokazać, że dialogu nie można sprowadzać jedynie do poziomu metody, ponieważ wyraża się on w sposób pełny dopiero w postawie dialogu otwartej na współuczestników dzięki gotowości wprowadzenia poprawek do własnych racji.

Prawdziwy dialog godny tego miana zakłada pełne poszanowanie przekonań, postawę otwarcia na prawdę, gotowość i chęć zrozumienia partnera dialogu, tak jak on sam siebie rozumie. Tak rozumiany dialog jest przede wszystkim stylem komunikowania się i działania, postawą i duchem, który przenika ludzkie relacje. Zakłada uwagę, szacunek i przychylność wobec drugiego człowieka, a także uznanie jego osobowej tożsamości, jego sposobów wyrażania siebie, jego wartości.

Taki właśnie dialog powinien być normą i stylem komunikowania się ludzi i budowania wszelakich relacji społecznych. Na takim fundamencie każdy rodzaj dialogu służyć będzie zarówno indywidualnemu dobru i rozwojowi każdego członka społeczności, jak i dobru wspólnemu zintegrowanych na fundamencie wartości ludzi. Taki dialog nie jest nieosiągalnym ideałem, ale realną

20 EŻ, s. 117. 
powinnością wszystkich ludzi tworzących jakąkolwiek wspólnotę.

\section{Zakończenie - laudacja końcowa}

W kontekście tych myśli, które tutaj przedstawiono, i moich chcę na koniec powiedzieć, że abp Józef Życiński, zaangażowany badawczo w obszar nauki, filozofii i teologii, uczy nas potrzeby solidnej metodologii w badaniach naukowych i otwiera na bogactwo świata ludzkiej racjonalności. Warto czerpać od niego inspirację i dobry metodologiczny klucz do korzystania z bogactwa refleksji współczesnej filozofii i metodologii nauki.

Od niego można się także uczyć życzliwego otwarcia na współczesne media i czerpać inspirację do odkrywania i pokazywania ich ludzkiego i personalistycznego oblicza. Jego odkrywcze i krytyczne diagnozy procesów i trendów współczesnej kultury medialnej i nowoczesnych prądów myślenia uczą krytycznego spojrzenia na drogi współczesnej kultury i współczesnych mediów, uczą potrzeby racjonalnego dialogu we wszystkich obszarach ludzkich poszukiwań prawdy i dobra. „Kult bożków znany starożytnym pojawia się jako kulturowe wyzwanie epoki deklarującej śmierć Boga, człowieka i sensu. [...] Formę przeciwdziałania nowej postaci kultu bożków winno stanowić wyodrębnienie podstawowego zbioru wartości ogólnoludzkich, który nie zależy od uwarunkowań społecznych czy kulturowych. Do zbioru tego należą wartości opatrywane w klasycznej tradycji mianem 
transcendentalnych. Stanowią je prawda, dobro i piękno. Wśród tych wartości winny znaleźć się także: godność osoby ludzkiej, wolność, miłość bliźniego, sprawiedliwość, solidarność, tolerancja” ${ }^{21}$. Niech te słowa abp. Józefa Życińskiego w kontekście współczesnego medialnego kultu bożków zabrzmią jak wołanie o potrzebę uniwersalnych wartości.

Jego odważne demaskowanie zaściankowości i postaw ekskluzywizmu oraz pokazywanie bzdur i mitów współczesnego myślenia lub jego całkowitego braku odsłaniają wartość i potrzebę racjonalności we wszystkich obszarach ludzkiego zaangażowania w odkrywanie sensu wartości i celu, także w kontekście współczesnego relatywizmu i ironii. $\mathrm{Na}$ zakończenie warto przytoczyć słowa abp. Józefa Życińskiego, które niech będą podsumowaniem tych refleksji: „Istnieje pewna sfera obiektywnych ludzkich wartości, których nie jest w stanie usunąć żaden przełom deklarowany czy to przez media, polityków, czy filozofów. Świat, w którym brakłoby pojęcia prawdy, wierności czy altruizmu, godności osoby ludzkiej, wolności, miłości bliźniego, sprawiedliwości, solidarności, tolerancji, byłby światem nieludzkim, nawet gdyby entuzjaści nowego ładu upatrywali w nim zalążków nowej ludzkości” ${ }^{22}$.

${ }^{21}$ Tamże, s. 42.

22 Tamże, s. 41.

Media - Kultura - Dialog. W piątą rocznicę śmierci arcybiskupa Józefa Życińskiego, red. ks. R. Nęcek, ks. W. Misztal, Kraków 2017, s. 181-198.

DOI: http://dx.doi.org/10.15633/9788374385848.16 